\title{
The incidence of insect pests and their Arthropod predators in 24 Canterbury white clover seed crops
}

\author{
NEIL SCHROEDER and PETER CLIFFORD \\ AgResearch Grasslands, P.O. Box 60, Lincoln
}

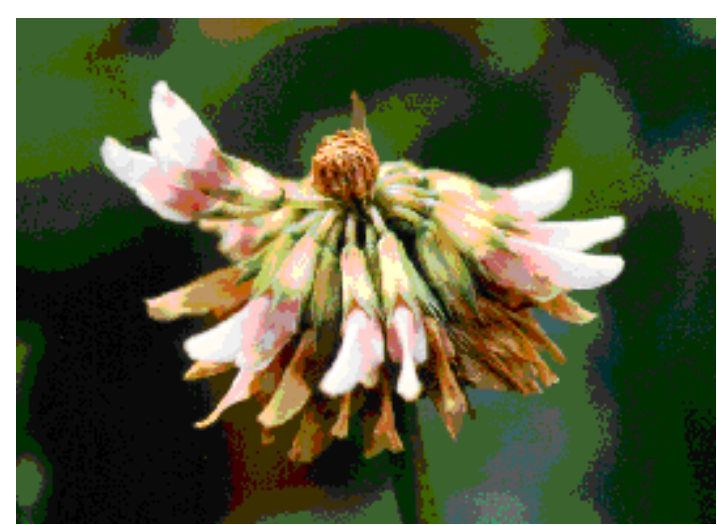

Plate 1: Central floret damage caused by mirid feeding.

\begin{abstract}
Insect pests and their predators were sampled in Canterbury white clover crops during the 1994-95 season. Bluegreen aphid and potato mirids occurred early (late October to mid-November) during the season and were a potential cause of major injury to developing flowerheads. Australian crop mirid, wheat bug, brown shield bug, and spittle bugs occurred later in the season during January and were more likely to affect seed fill and resultant seed quality. Bluegreen aphids reached an overall maximum number of 800 per $\mathrm{m}^{2}$ during early December, while potato mirid nymphs and adults were found in significantly $(\mathrm{P}<0.001)$ higher numbers in the field edges reaching maximum numbers of 40 and 5.7 per $\mathrm{m}^{2}$ in early December and mid-December, respectively. Of the five species of arthropod predators collected, lacewing larvae and ladybird adult and larvae numbers were positively $(\mathrm{P}<0.01,0.001,0.05$, respectively) correlated to bluegreen aphid numbers. Selective insecticides should be applied to conserve arthropod predator populations, while controlling hemipteran pest numbers.
\end{abstract}

Keywords: bluegreen aphid, hemipteran, lacewing, ladybird, pests, potato mirid, predators, seed production, white clover

\section{Introduction}

The primary pests of white clover (Trifolium repens $\mathrm{L}$.) seed crops have long been considered to be the clover casebearers (Coleophora spissicornis Haworth and $C$. frischella $\mathrm{L}$.), but since the successful introduction of the two parasitoids, Bracon variegator (Nees) and Neochrysocharis sp., for clover casebearer control, there has been a large reduction in the amount of insecticide being applied (Pearson 1991). Lack of insecticide use has led to an increase in flowerhead damage (Plate 1) caused by hemipteran pests (bugs) commonly found within the crops.

The common hemipteran pests found in white clover crops are bluegreen aphid (Acyrthosiphon kondoi Shinji), potato mirid (Calocoris norvegicus Gmelin), brown shield bug (Dictyotus caenosus Westwood), Australian crop mirid (Sidnia kinbergi Stål), and wheat bug (Nysius huttoni White) (Schroeder 1995, Wightman and MacFarlane 1981). Although the occurrence of potato mirid and other hemipteran pests coincides with white clover flower development, little is known about their impact on seed yield components. Schroeder (1995) found that potato mirid nymphs at a density of 34-48 per $\mathrm{m}^{2}$ may cause up to $148 \mathrm{~kg} / \mathrm{ha}$ loss in seed yield, corresponding to a loss of $\$ 592$ per ha at $\$ 4$ per $\mathrm{kg}$. Four bluegreen aphids per flowerhead did not significantly reduce seed yields, but at infestations above 16 aphids per head Trought (1977) predicted that $20 \%$ seed yield losses could occur.

Predatory arthropods feed on insect pests found in the crop. The predatory arthropods commonly found in white clover crops are the eleven spotted ladybird (Coccinella undecimpuncata L.), Pacific damselbug (Nabis kinbergii Reuter), money spiders (mainly Lepthyphantes tenuis Blackwell), hoverfly larvae (Melangyna novaezelandiae Macquart and Melanostoma fasciatum Macquart), and harvestmen (Phalangium opilio L.) (Schroeder 1995). Over 70\% of the gut contents from the four most abundant predators (Pacific damselbug, eleven spotted ladybird, Tasmanian lacewing, and harvestman) found in a Lincoln lucerne crop gave positive precipitin reactions to aphid-induced rabbit antiserum (Leathwick \& Winterbourn 1984), suggesting that aphids were the preferred host and that 
these predators could have a considerable impact on aphid populations. Single predators placed in cages containing 40 third and fourth instar pea aphids devoured 73\% (lacewing), 84\% (harvestman), and 70\% (ladybird) of aphids within a 48 hour period (Leathwick and Winterbourn 1984). High numbers of harvestmen were collected at night-time and are considered to be a major aphid predator by Leathwick and Winterbourn (1984) in lucerne crops.

During a preliminary survey of insects populations in seven Lincoln white clover crops during the 1993-94 season bluegreen aphids occurred at the highest densities (over 300 per $\mathrm{m}^{2}$ ), while potato nymphs occurred predominantly in the field edges and later in the season as mobile adults throughout the crops (Schroeder 1995). It was found that because of the large numbers of aphids present growers were more likely to apply insecticides for their control rather than for the control of other hemipteran species commonly found in the crops. Schroeder and Chapman (1995) concluded that more effective insect pest control could be achieved through better timing of insecticide applications and that identification of key economic insect pests was still required.

A detailed crop monitoring survey of arthropod populations was conducted in 24 first year Grasslands Huia white clover seed crops in the Canterbury growing region during the 1994-95 season to study the incidence and distribution of pest insects and their arthropod predators within the crops. This paper examines the combined results of the data collected from the 24 crops monitored. Emphasis is given to those insect pests found in the crops during the flowering period as they are those most likely to have detrimental effects on flowerhead development.

\section{Materials and methods}

Three first year Grasslands Huia crops from each of the following areas; Ashburton/Rakaia, Coastal Ashburton, Darfield, Lincoln, Methven, Sheffield, Southbridge, and Timaru, were suction sampled every two weeks, from 15 November until harvest (last sample at Southbridge 9 February). Field sizes averaged around 8 hectares and ranged from 6.4 to 18 hectares. Each crop was sampled at five positions from the edge into the crop ('edge', $15 \mathrm{~m}, 30 \mathrm{~m}$, 'halfway' between $30 \mathrm{~m}$ and 'centre', and the crop 'centre') to determine the field invasion and distribution of both pests and their predators within the crop. The suction sampler consisted of a two-stroke Stihl (BG72) motor mounted on a collection container covering a $201 \mathrm{~cm}^{2}$ suction area. Each sample consisted of four lots of 10 suctions (total $0.804 \mathrm{~m}^{2}$ ) per position. Samples were suctioned from areas of good white clover growth. Weed infested and bare patches were avoided. Flower counts, cloud cover and temperatures were also recorded at each field visit and strips of $5 \mathrm{~m} \times 45 \mathrm{~cm}$ $\left(2.25 \mathrm{~m}^{2}\right)$ were mown at harvest and seed yield results from each field sampling area were recorded. The mown areas were selected for their good clover growth and were not necessarily representative of the overall crop area. Results from the mown areas, therefore assume a uniform crop.

\section{Results}

The following results are of overall data collected from the 24 monitored fields. Further analysis will determine differences between the eight growing areas and individual fields but these data are not included in this paper.

Of the 24 fields surveyed, 19 were untreated with insecticide, but two growers had applied pirimicarb (Pirimor) and three had applied fluvalinate (Mavrik) for aphid control. The Mavrik-treated crops were all in the same area (Southbridge) and numbers of aphids and mirids prior to application were low and remained the lowest over all fields following spray application.

\section{Insect Pests}

Peak incidence of the most abundant insect pests occurring within the 24 fields during the season and their respective maximum densities are given in Figure 1. The combined adult population of both clover casebearer species reached a maximum of 0.69 per $\mathrm{m}^{2}$ during late November-early December. The combined peak flowering occurred around December 14 (Figure 1), which was one week earlier than usual.

The highest number of potato mirid nymphs (154 per $\mathrm{m}^{2}$ ) were collected in the Methven crop edges in early December, indicating that at the higher altitude of $330 \mathrm{~m}$ above sea level there was little effect on distribution. Both nymph (Figure 2) and adult potato mirid numbers were significantly $(\mathrm{P}<0.001)$ higher in the field edges than in positions further into the crop. Overall nymph numbers in the edges reached a maximum 40 per $\mathrm{m}^{2}$ during early December (Figure 2), while adults recorded a maximum 5.7 per $\mathrm{m}^{2}$ in the edges during mid-December. Adult potato mirids collected from the Timaru crops reached maximum numbers one month later in mid-January. This delay might have been caused by the cooler growing conditions in this area. There was also a combined significant $(\mathrm{P}<0.001)$ decrease in seed yields from the centres of the crops to the field edges, estimated yields at the five sampling positions decreasing from $414.5 \mathrm{~kg} \cdot \mathrm{ha}^{-1}$ at the centre, through $361,376,354$ to $275 \mathrm{~kg} \cdot \mathrm{ha}^{-1}$ at the field edges. 
Figure 1: Insect pest peak numbers during the 1994-95 season (shaded area indicates overall flowering pattern).

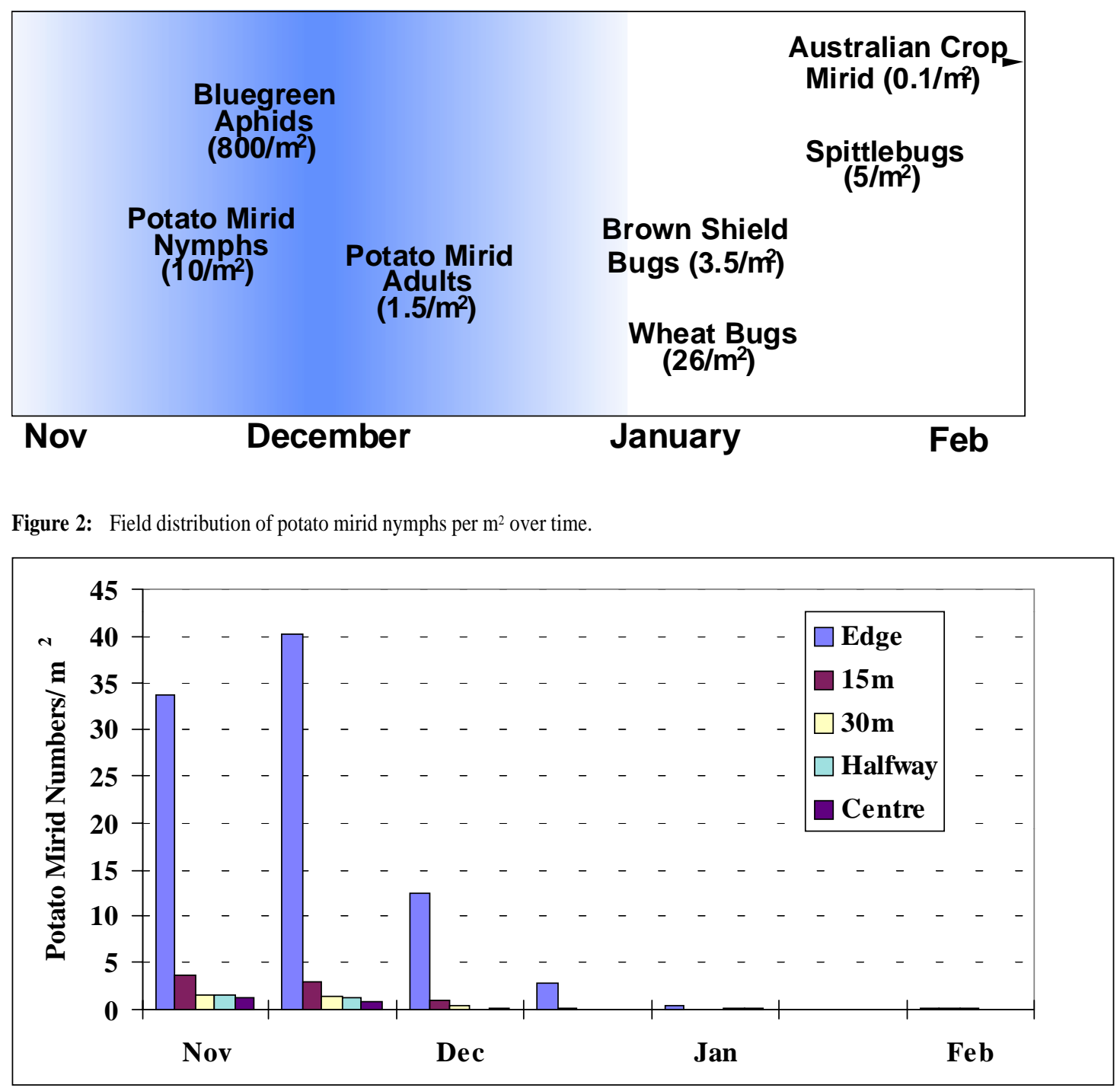

Bluegreen aphid numbers reached an overall peak of 800 per $\mathrm{m}^{2}$ in early December and decreased thereafter (Figure 3). This peak in aphid numbers had a range from 133 (Southbridge) to 1750 per $\mathrm{m}^{2}$ (Ashburton/ Rakaia). However, in Darfield and Sheffield aphid numbers reached a maximum 2235 per $\mathrm{m}^{2}$ and 786 per $\mathrm{m}^{2}$, respectively, during the following two weeks and appeared to be closely associated with inflorescence density.

\section{Arthropod Predators}

While bluegreen aphid numbers were at a maximum during the early December period, combined adult and larvae numbers of ladybirds and lacewings reached a maximum of 13.6 per $\mathrm{m}^{2}$ and 17.2 per $\mathrm{m}^{2}$ in mid to late December, respectively (Figure 3). All three species decreased rapidly in density after reaching their respective maximum numbers. There was a significant positive correlation between the numbers of bluegreen aphids and ladybird adult $(\mathrm{P}<0.001)$ and larvae $(\mathrm{P}<0.05)$, and lacewing larvae $(\mathrm{P}<0.01)$ numbers (Figure 3$)$. Other predators that were collected in samples were money spiders which ranged in overall density from 12 per $\mathrm{m}^{2}$ (late November to early December) to 27 per $\mathrm{m}^{2}$ (midJanuary), hoverfly larvae which reached an overall maximum of 1.7 per $\mathrm{m}^{2}$ in mid-December and early 
Figure 3: Mean overall densities of bluegreen aphids and their predators (combined larval and adult ladybirds and lacewings) during the 1994-95 season. Note the different $y$-axis densities given for bluegreen aphid (left) and combined predators (right).

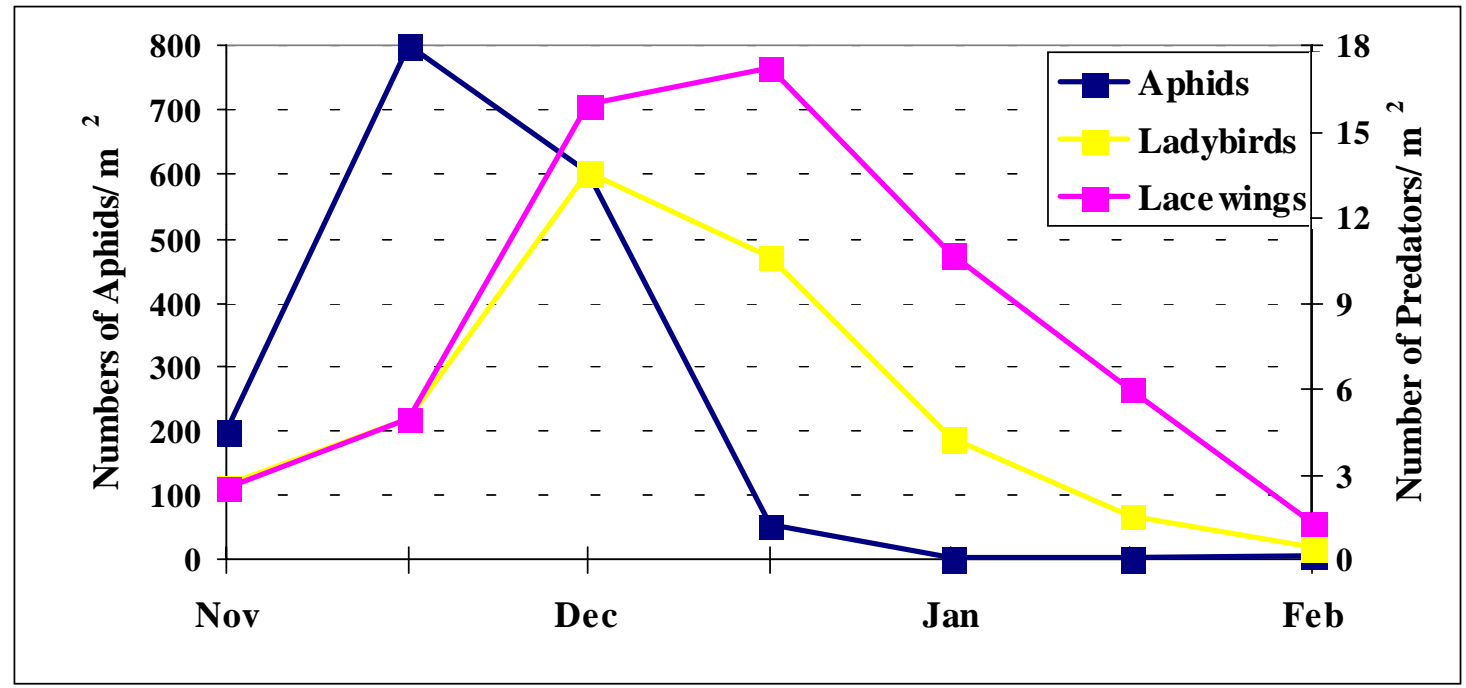

February, and harvestmen which peaked in numbers at 3.7 per $\mathrm{m}^{2}$ in mid-December and significantly $(\mathrm{P}<0.001)$ decreased in numbers from the edge $\left(3.8\right.$ per $\left.\mathrm{m}^{2}\right)$ towards the centre $\left(1.5\right.$ per $\left.\mathrm{m}^{2}\right)$.

\section{Discussion}

This paper has examined the major trends of insect pest arthropod predator distribution throughout the whole of Canterbury. Specific growing area details will be combined with future survey work to determine any seasonal variations. The results help to identify those pests which are most likely to significantly affect flowerhead development (bluegreen aphid and potato mirid) and, later, seed quality at the seed fill stage (Australian crop mirid, wheat bug, brown shield bug, and spittle bugs). Warmer seasons may see the latter insects in the crops earlier and contributing to flowerhead damage. Knowledge of the field distribution of these insects will be instrumental in developing control programmes, such as strategic insecticide application. However, it must be stressed that the economic impact of these pests requires further investigation to determine their importance. Seed yield losses at the crop edge could partly be attributed to high potato mirid densities in the edges. How far into the crop this damage occurs requires further detailed investigation. Control of potato mirid at the edge may prevent invasion into the field and into neighbouring crops of mobile adults later in the season (Figure 1).

The flowerhead injury caused by all the hemipterans, except bluegreen aphid, is similar to that shown in Plate 1. These species inject the feeding site with salivary enzymes, which destroy cell walls, so that their contents can be sucked up by the insect. Pearson (1991) found evidence that Australian crop mirid feeding enzymes may travel within plant tissue causing plant injury not only at the feeding site. Potato mirid feeding damage, on the other hand, seems to be localised to the feeding site (Michailides et al. 1987). Potato mirids were shown to be more abundant during flowerhead development than Australian crop mirids (Figure 1).

Bluegreen aphids feed by tapping in to the plant phloem system and syphoning off the nutrients. A large outbreak is more likely to cause water stress to the plant, impacting non-irrigated crops more than irrigated.

The arthropod predators collected during this study were predominantly aphid feeders. There was a delayed increase in predator densities compared to aphid densities in the present study (Figure 3). The reduction in aphid numbers by the application of a selective aphicide may reduce this build-up, while preserving predator numbers to control later aphid numbers. It is not known what impact these predators may have on potato mirid numbers. Of the predators collected, harvestmen are the most likely to prey upon potato mirid nymphs. However, it is probable that the highly mobile nymphs and adults will be harder for the predator to subdue compared to the preferred slower moving and aggregated populations of aphids.

Future study will focus on the crop invasion and distribution of bluegreen aphid and potato mirids in 
relation to crop phenology and yield components. Once the ecology of these insect pests is understood and their economic importance established, then strategic timing and application of control tactics can be employed.

\section{Acknowledgements}

The author would like to thank AgResearch staff, Gareth Davidson for technical support and David Baird for the analysis of data.

\section{References}

Leathwick, D.M.; Winterbourn, M.J. 1984. Arthropod predation on aphids in a lucerne crop. New Zealand Entomologist 8: 75-80.

Michailides, T.J.; Rice, R.E.; Ogawa, J.M. 1987. Succession and significance of several hemipterans attacking a pistachio orchard. Journal of Economic Entomology 80: 398-406.

Pearson, W.D. 1991. Effect of meadow spittlebug and Australian crop mirid on white clover seed production in small cages. New Zealand Journal of Agricultural Research 34: 439-444.

Schroeder, N.C. 1995. Hemipteran pest damage assessment and management in white clover seed crops. M.Agr.Sci Thesis, Lincoln University, New Zealand.

Schroeder, N.C.; Chapman, R.B. 1995. The impact of two insecticides on hemipteran pests and beneficial arthropods in a white clover seed crop. Proceedings of the 48th New Zealand Plant Protection Conference. pp. 170-174.

Trought, T.E.T. 1977. Control of blue-green lucerne aphid on white clover seed crops. Proceedings of the New Zealand Weed and Pest Control Conference 30: 188-191.

Wightman, J.A.; MacFarlane, R.P. 1981. The integrated control of pests of legume seed crops: 2 . Summation and strategy of the 1980-81 season. Proceedings of the 3rd Australasian Conference of Grassland Invertebrate Ecology. pp. 377-384. 
